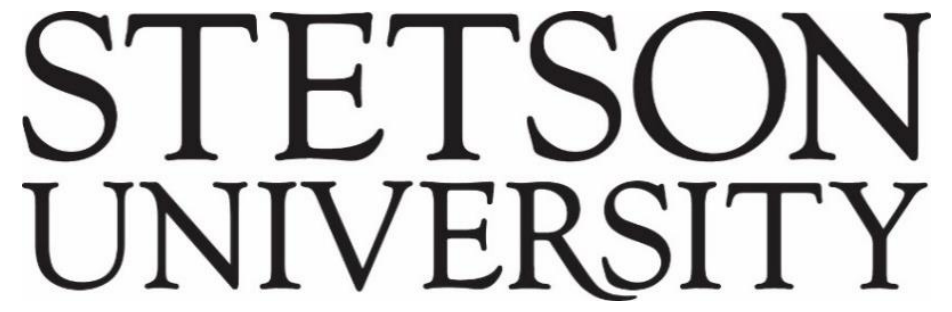

Voices of Reform: Educational Research to Inform and Reform

Volume $2 \bullet$ Issue $1 \bullet$ Article 2

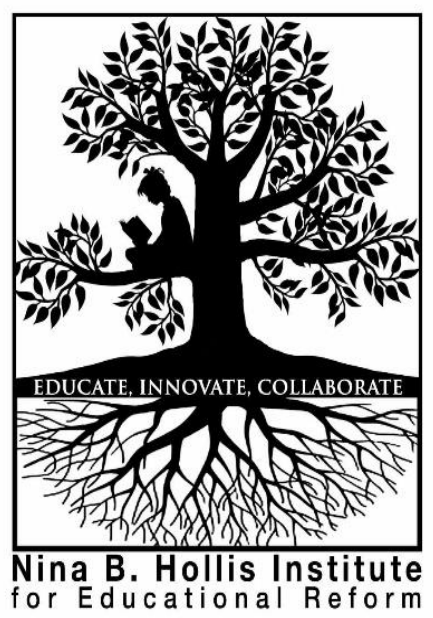

September 2019

\title{
Using First-Year Seminar Courses to Improve Performance Funding Outcomes - A Case Study of the State of Florida
}

\author{
Masha Krsmanovic \\ University of Central Florida
}

Follow this and additional works at: http://www.voicesofreform.com

Recommended Citation

Krsmanovic, M. (2019). Using first-year seminar courses to improve performance funding outcomes - A case study of the State of Florida. Voices of Reform, 2(1), 24-44. Retrieved from https://www.voicesofreform.com/article/10608-using-first-year-seminar-courses-to-improve-performance-fundingoutcomes-a-case-study-of-the-state-of-florida doi: 10.32623/2.00004

http://dx.doi.org/10.32623/2.00004

Revisions

Submission date: March $5^{\text {th }}, 2019$

$1^{\text {st }}$ Revision: April $16^{\text {th }}, 2019$

Acceptance: April 22 $2^{\text {nd }}, 2019$

Publication date: September 30 ${ }^{\text {th }}, 2019$ 


\title{
Using First-Year Seminar Courses to Improve Performance Funding \\ Outcomes - A Case Study of the State of Florida
}

\author{
Masha Krsmanovic ${ }^{1}$ \\ ${ }^{1}$ College of Community Innovation and Education \\ University of Central Florida, United States \\ masha.krsmanovic@ucf.edu
}

\begin{abstract}
This case study examined the connection of First-Year Seminars (FYS) and Performance Funding outcomes in the State of Florida. The comparison of Florida State performance metrics and the empirical evidence on the effectiveness of FYS on these metrics was conducted to determine which performance metrics, if any, can be indirectly supported by student participation in the course. The findings demonstrate that, for the state of Florida, FYS can be used as an intervention to promote the following four metrics common to all institutions: (1) academic progress rate, (2) four year graduation rate, (3) average cost to the student, and (4) percent of bachelor's graduates enrolled or employed. Additionally, the seminars can potentially be utilized to support institutional effectiveness in the two choice metrics (i.e. metrics chosen by the institutional Board of Trustees): (1) bachelor's degrees awarded to minorities and (2) bachelor degrees awarded annually. Implications and recommendations for future research are discussed.
\end{abstract}

\section{Keywords}

Performance funding, first-year seminars, student outcomes

\section{Introduction}

The number of states adopting Performance Funding (PF) models is increasing each year. The common objective behind this trend is to maximize effectiveness and resourcefulness of public institutions by stimulating student performance, retention, and degree attainment. By the end of 2015, 33 states adopted PF models with several more states announcing their intention to implement these programs in the next few years (Dougherty, Jones, Lahr, Natow, Pheatt, \& Reddy, 2016). 
The widespread adoption of PF models, however, places an urgent demand on participating colleges and universities to formulate new or reinvent existing institutional effectiveness plans in a way that would best support their improvement in the targeted areas. To this day, there is very little research on how the institutions that adopt PF models navigate the organizational learning in this area, develop strategies for responding to their metrics, and execute this important decisionmaking process (Dougherty et al, 2016). What makes this scholarly gap even more alarming is the fact that assessing the performance of higher education institutions (HEIs) surfaced as a muchneeded educational reform issue back in the mid-1980s (Burke, 2002).

At the same time, HEIs are certainly not lacking initiatives for designing, piloting, and practicing a wide variety of strategies aimed to promote student success. Among these initiatives, First-Year Seminars (FYS) have received a growing scholarly and practical attention as an intervention specifically designed to not only support student academic and social integration, but to pave a steady path to their timely graduation.

The most recent survey on First-Year Seminars revealed that, among the responding institutions, 89.7\% reported offering a course of this kind to their incoming students (NRCFYEST, 2013). The strong reliance on using FYS courses to improve student outcomes is substantiated by the same data which revealed that for more than half of these institutions seminars constituted a general education requirement. Credit hours were another indicator of the value placed on FYS seminars. The majority of surveyed institutions designed their seminars as three-credit hour classes (40\%), while the remaining ones offered these classes as either one credit (30\%) or two-credit hour courses (10\%). According to the Institute of Education Sciences (2016), the most pronounced outcomes of the seminars were found to be in the areas of credit completion, academic achievement, and degree attainment.

The expansion of FYS offerings is commensurate with the research efforts directed toward evaluating their effectiveness on not only traditional measures of student success (i.e. performance, retention, graduation), but also on many other factors proven to affect student performance. In this regard, the scholarship is becoming increasingly interested in comparing the benefits of different types of FYS courses, assessing the course impacts on diverse student populations, identifying less frequently recorded course outcomes, and many other, not commonly explored factors. However, the potential of FYS courses to serve as a tool for improving performance funding outcomes seems to be absent from contemporary literature.

In order to overcome such limitation, this study examined the following research question:

How effectively can First-Year Seminar (FYS) courses be used to improve Performance Funding (PF) outcomes?

Due to the scope of the research problem addressed in this study, the investigation was limited to the case of the State of Florida. The research question was examined by conducting a review and analysis of the existing evidence in the two examined domains: a) the Performance Funding metrics in the State of Florida b) the effectiveness of FYS courses on these metrics. 
Consequently, the overarching purpose of this study was to promote educational reform in both states that already implemented PF programs and those that announced adopting this practice over the next few years. Overall, this study was designed to provide all catalysts of educational reform with historical evidence on the connection between First-Year Seminars and PF metrics and the ways in which this high impact practice can be more strategically used to maximize institutional effectiveness.

\section{Literature Review}

\section{Performance Funding}

Performance funding ties state funding directly to institutional performance, measured in terms of student outcomes and other outcomes-based metrics, most commonly student persistence, completion of specific courses, degree attainment, and job placement (Dougherty et al., 2016) Among the 33 states that adopted FB by the end of 2015, two different models were applied. Type 1.0 was implemented by those institutions who, upon meeting their funding metrics, received a bonus above their regular state funding. On average, this bonus varied between $1 \%$ and $5 \%$ of the state funding. Examples of such program include Tennessee, Florida, and Ohio. On the other hand, performance funding 2.0, usually referred to as outcomes-based funding, designates regular state base funding for colleges and universities. Notable examples include Pennsylvania, Indiana, Ohio, and Tennessee (Dougherty \& Natow, 2015).

As illustrated in Table 1, 15 states implemented PF model 2.0, while 12 states followed model 1.0. The remaining six states - Florida, Hawaii, Indiana, North Dakota, and Wyoming had PF types 1.0 and 2.0, which means that their funding models included both a bonus above the regular state funding and the regular state funding.

Among the states that implemented PF, additional variances exist, primarily in terms of the proportion of state money subject to the funding, the type of public institutions included in the model (i.e. two and four year), and student population prioritized (e.g. underrepresented, low socioeconomic status, non-traditional students, specific major, etc.). As presented in Table 1, even though the majority of these 33 states applied PF to all public institutions, some states limited its application to either 2-year colleges or 4-year universities. The states that restricted the implementation of PF to 2-year colleges only included Hawaii, North Carolina, Texas, Washington, Wisconsin, and Wyoming. On the other hand, in Arizona, Maine, Mississippi, Oregon, and Pennsylvania, only 4-year institutions were subject to such funding.

While the funding for the majority of these states was dependent on the outcomes of special student populations, 10 states choose not to prioritize any particular student group. Among the special student populations whose outcomes determined the institutional appropriations, the most prevalent group were students with low socioeconomic status (16 states), as well as underrepresented minorities (seven states). Lastly, 20 states whose funding was determined by the outcomes tied to a special student population prioritized several different groups simultaneously (e.g. non-traditional students or specific majors, such as STEM). 
Table 1: The Overview of Performance Funding Models in the United States (2015)

\begin{tabular}{|c|c|c|c|}
\hline State & PF Type & Institution Type & $\begin{array}{l}\text { Special student } \\
\text { group }\end{array}$ \\
\hline Arizona & 1.0 & 4 year & Yes \\
\hline Arkansas & 2.0 & 2 year, 4 year & Yes \\
\hline Colorado & 2.0 & 2 year, 4 year & Yes \\
\hline Florida & $1.0,2.0$ & 2 year, 4 year & Yes \\
\hline Hawaii & $1.0,2.0$ & 2 year & Yes \\
\hline Illinois & 2.0 & 2 year, 4 year & Yes \\
\hline Indiana & $1.0,2.0$ & 2 year, 4 year & Yes \\
\hline Kansas & 1.0 & 2 year, 4 year & No \\
\hline Louisiana & 2.0 & 2 year, 4 year & No \\
\hline Maine & 2.0 & 4 year & Yes \\
\hline Massachusetts & 2.0 & 2 year, 4 year & Yes \\
\hline Michigan & 1.0 & 2 year, 4 year & Yes \\
\hline Minnesota & 2.0 & 2 year, 4 year & Yes \\
\hline Mississippi & 2.0 & 4 year & Yes \\
\hline Missouri & 1.0 & 2 year, 4 year & No \\
\hline Montana & 2.0 & 2 year, 4 year & No \\
\hline Nevada & 2.0 & 2 year, 4 year & Yes \\
\hline New Mexico & 2.0 & 2 year, 4 year & Yes \\
\hline New York & 1.0 & 2 year, 4 year & Yes \\
\hline North Carolina & 1.0 & 2 year & No \\
\hline North Dakota & $1.0,2.0$ & 2 year, 4 year & No \\
\hline Ohio & 2.0 & 2 year, 4 year & Yes \\
\hline Oklahoma & 1.0 & 2 year, 4 year & Yes \\
\hline Oregon & 1.0 & 4 year & Yes \\
\hline Pennsylvania & 2.0 & 4 year & Yes \\
\hline South Dakota & 1.0 & 2 year, 4 year & Yes \\
\hline Tennessee & $1.0,2.0$ & 2 year, 4 year & Yes \\
\hline Texas & 2.0 & 2 year & Yes \\
\hline Utah & 1.0 & 2 year, 4 year & No \\
\hline Virginia & 1.0 & 2 year, 4 year & No \\
\hline Washington & 1.0 & 2 year & No \\
\hline Wisconsin & 2.0 & 2 year & Yes \\
\hline Wyoming & $1.0,2.0$ & 2 year & No \\
\hline
\end{tabular}

\section{Florida Performance Funding}

The Performance Funding model currently used in the state of Florida was established by the Florida Board of Regents in 2013. This model involves both PF types 1.0 and 2.0 with bonus funding and performance indicators embedded in the base state funding. Prior to 2013, the state of Florida operated under the Performance-Based Budgeting model (1996-2008) and the Workforce 
Development Education Fund (1997-2002). The first model included only the state's community colleges to which the funds were distributed based on their performance on three indicators: awarded certificates, the associate of arts degrees, and associate of science degrees. Also limited to community colleges only, the second model included different performance measures: adult basic education completions, vocational certificates, the vocational associate of science for certain student populations, and job placement (Dougherty \& Natow, 2015).

The current PF model includes 10 metrics used to evaluate institutional effectiveness and determine the allocation of state funds. Of these 10 metrics, two are Choice metrics which means that one performance indicator is selected by the Board of Governors and one by the institutional Board of Trustees. Table 2 illustrates seven metrics that are applied to all higher education institutions in Florida and metric eight which is applied to all institutions except New College. Metric nine represents Board of Governors' choice metric, also common to all institutions. Lastly, metric 10 refers to a choice metric selected by the institutional Board of Trustees as the most relevant for the mission of a particular college or university.

Table 2: The Overview of Florida Performance Funding Metrics (2018)

\section{Performance Funding Metrics}

1 Percent of bachelor's graduates employed or continuing their education

2 Median wages of bachelor's graduates employed full-time

$3 \quad$ Average cost to the student

4 Four-year graduation rate

$5 \quad$ Academic progress rate

6 Bachelor's degrees awarded in areas of strategic emphasis

$7 \quad$ University access rate

8 a Graduate degrees awarded in areas of strategic emphasis

$8 \mathrm{~b} \quad$ Freshman in top $10 \%$ of graduating high school class (New College of Florida only)

$9 \quad$ Board of Governors choice - Percent of bachelor's degrees without excess hours

10 Board of Trustees choice

Adapted from: Performance Based Funding Overview, Florida Board of Governors, 2018

Metric 10 represents a performance measure selected by the institutional Board of Trustees which was deemed as the most relevant to the mission of a particular college or university. Table 3 provides an overview of this metric for the higher education institutions in the State University System of Florida. 
Table 3: The overview of Board of Trustees Choice Metrics

\begin{tabular}{|c|c|c|}
\hline & Institution & Metric \\
\hline $10 \mathrm{a}$ & $\begin{array}{l}\text { Florida Agricultural and } \\
\text { Mechanical University }\end{array}$ & $\begin{array}{l}\text { Percent of research and development expenditures } \\
\text { funded from external resources }\end{array}$ \\
\hline $10 \mathrm{~b}$ & $\begin{array}{l}\text { Florida Atlantic } \\
\text { University }\end{array}$ & Bachelor's degrees awarded to minorities \\
\hline $10 \mathrm{~b}$ & $\begin{array}{l}\text { Florida Gulf Coast } \\
\text { University }\end{array}$ & Bachelor's degrees awarded to minorities \\
\hline $10 \mathrm{~b}$ & $\begin{array}{l}\text { Florida International } \\
\text { University }\end{array}$ & Bachelor's degrees awarded to minorities \\
\hline $10 \mathrm{c}$ & Florida State University & $\begin{array}{l}\text { National rank higher than predicted by financial resources } \\
\text { ranking based on a US and World News Report }\end{array}$ \\
\hline $10 \mathrm{~d}$ & New College of Florida & $\begin{array}{l}\text { Percent of undergraduate seniors participating in a } \\
\text { research course }\end{array}$ \\
\hline $10 \mathrm{e}$ & $\begin{array}{l}\text { University of Central } \\
\text { Florida }\end{array}$ & Number of bachelor's degrees awarded annually \\
\hline $10 \mathrm{f}$ & University of Florida & Number of licenses/options executed annually \\
\hline $10 \mathrm{~g}$ & $\begin{array}{l}\text { University of North } \\
\text { Florida }\end{array}$ & Percent of undergraduate FTE in online courses \\
\hline $10 \mathrm{~h}$ & $\begin{array}{l}\text { University of South } \\
\text { Florida }\end{array}$ & Number of postdoctoral appointees \\
\hline $10 \mathrm{i}$ & $\begin{array}{l}\text { University of West } \\
\text { Florida }\end{array}$ & $\begin{array}{l}\text { Number of undergraduate students aged } 25 \text { and } \\
\text { older enrolled in Fall }\end{array}$ \\
\hline
\end{tabular}

Adapted from: Performance Based Funding Overview, Florida Board of Governors, 2018

\section{First-Year Seminars}

The importance of helping first-year students transition to the new academic environment was recognized early in American higher education. However, several factors influenced the expansion of First-Year Seminars to happen during the early 1970s. First, changes in university admissions criteria allowed access to students who had previously been excluded from or underrepresented on college campuses (e.g. minorities, women, non-traditional students). Consequently, it was not uncommon for these students to arrive on campus lacking the required academic skills and needing additional guidance to adjust successfully. Additionally, new and diverse courses were added to university curricula, thus creating a more complex educational system for students to navigate. As 
a result, FYS began to receive a more prominent role in American higher education and have enjoyed a steady expansion ever since (Gordon, 1991).

Barefoot and Fidler (1992) identified five types of FYS seminars, creating a typology that has not changed much since it was first introduced. The five seminar types included: a) extended orientation seminar, b) academic seminar with uniform content across sections, c) academic seminar on various topics, d) pre-professional or discipline-linked seminar, and d) basic study skills seminar. To these five types, National Resource Center added the sixth category - a hybrid FYS or a course that encompasses the characteristics of two or more seminar types.

According to the latest survey of First-Year Seminars, conducted in 2013, the top three course outcomes reported by the responding institutions were: a) developing a connection with the institution, b) providing orientation to campus resources and services, and c) developing academic skills. In terms of the FYS type, approximately $40 \%$ of HEIs offered an extended orientation seminar format and a nearly similar percentage of institutions offered an academic-themed seminar. In terms of institutional type, $61.7 \%$ of courses were offered at four-year colleges and universities and $38.3 \%$ at two-year institutions. Private institutions were more likely to host a FYS course $(62 \%)$ than public colleges and universities $(38 \%)$.

The three most frequently reported categories of students required to take a FYS course were: a) academically underprepared students, b) students from specific academic majors, and c) students enrolled in developmental or remedial courses. In public institutions, FYS courses were usually mandatory for academically underprepared students, students enrolled in developmental courses, provisionally admitted students, and students participating in student support programs such as TRIO (National Resource Center, 2013).

The most recent and future directions of research on FYS courses are highly dynamic and hard to anticipate. Scholars are moving away from assessing the traditional student success measures, such as retention and GPA, towards exploring less known course effects (e.g. development of soft skills, career readiness, learning behaviors, motivation, self-regulation, and other life-long skills and competencies). Additionally, the literature is becoming increasingly concerned with the potency of the course to support diverse student groups, as well as with identifying the student groups that benefit most from participation in the seminar. The research in this particular domain, however, is still scarce and needs to be brought up to date. On the other hand, a comparison of seminar types, curricula, or even delivery method represents a recent novelty in the research in this field. In that regard, this research study sought to advance the existing knowledge and add to the continuously expanding research on FYS courses by exploring the role of the course in a not yet investigated context - performance funding.

\section{The Relationship between Performance Funding and First-Year Seminars}

While PF models stipulate very specific and clearly defined outcomes, policymakers do not prescribe any strategies, programs, or initiatives to be used for accomplishing these outcomes. Instead, they entrust each institution to develop its own action steps and design effective programming that can promote the fulfillment of performance outcomes (Dougherty et al., 2016). As a result, in states with PF models, higher education policymakers, faculty, and staff become the 
catalysts of reform by ensuring that all campus entities join their efforts toward accomplishing common outcomes.

The scholarly evidence in this area, however, documents that efforts to reform educational practices to be better aligned with PF outcomes are usually limited to four specific areas: a) reforming institutional spending; b) reforming academic policies and programs; c) reforming academic support services; and d) reforming the policies regulating student services (Dougherty $\&$ Reddy, 2013). As FYS courses are most commonly defined as the intervention programs designed to facilitate students' integration and development (Hunter \& Lindner, 2005), the recommendation for reforming academic policies and programs becomes particularly relevant in the context of this study.

Among the institutions that attempted to improve PF outcomes by reforming their academic policies and programs, specific interventions were usually very limited in scope. In most cases these interventions included one of the following three initiatives: a) eliminating academic programs with low graduation requirements, b) revising existing graduation requirements, and c) initiating professional development for faculty in the courses of greatest student concern (Dougherty \& Reddy, 2013). In that regard, this study sought to examine if there is a sufficient and compelling empirical evidence to support the argument that such reform of academic policies and programs should be expanded to include the strategic utilization of FYS courses.

\section{Methodology}

The research question was examined by conducting a review and analysis of: a) the Performance Funding metrics in the State of Florida and b) the empirical evidence of the effectiveness of FYS courses on these metrics. Case study research was selected as the most appropriate method for investigating this question due to several reasons. First, a case study is defined as an in-depth study of one or more instances of the phenomenon. Second, case studies are generally used for either: a) producing detail descriptions of the phenomenon, b) developing possible explanations of it or c) evaluating the phenomenon (Gall, Gall, \& Borg, 2007). Similarly, the purpose of this research was to produce a detail description and explanation of the PF system in the State of Florida, as well as the empirical evidence on FYS effectiveness. In addition, this research sought to evaluate the FYS potency to serve as an intervention for improving PF outcomes.

As every case study is bounded by clearly defined parameters, such as place and time (Yin, 2009), the unit of analysis for this study was defined by pre-established boundaries of the case. Thus, the description and analysis of Performance Funding models were limited to the State of Florida. This case was examined using the sample of 11 institutions which are the members of the State University System of Florida (Table 3).

The analysis and evaluation of the effectiveness of FYS courses on PF metrics were limited to peer-reviewed empirical evidence disseminated through several publication sources: refereed articles, books or book chapters, dissertations, and technical reports. The sample of empirical studies was further bounded by the year of publication and research setting. Due to the lack of a more recent evidence in some domains of FYS scholarship, the final sample of the explored 
empirical research included the findings from the past 20 years (i.e. 2008-2018). The research setting was limited to the FYS in the United States.

\section{Findings}

The comparison of Florida State PF metrics and the empirical evidence on the effectiveness of FYS was conducted to determine which PF metrics, if any, are connected to FYS course impacts. In that regard, the findings demonstrate that, for the state of Florida, FYS courses be used as an intervention to promote five metrics common to all institutions and two metrics chosen by the Board of Trustees (i.e. metric 10).

\section{Metric 1: Academic Progress Rate}

This measure refers to second-year retention with a GPA above 2.0. An institutional performance is measured calculating the percentage of First-Time in College (FTIC) students first enrolled in Fall (or summer continuing to Fall) who were still enrolled in the same institution in the following Fall and who completed their first year of studies with a minimum GPA of 2.0 (Florida Board of Governors, 2018). As presented in Table 4, the overall score for this metric for the institutions in the State University System of Florida was 5.19, indicating the need for additional improvement in this area.

Table 4: Institutional Scores for Academic Progress Rate in 2017-2018

\begin{tabular}{lc}
\hline \multicolumn{1}{c}{ Institution } & Score \\
\hline Florida Agricultural and Mechanical University & 0 \\
Florida Atlantic University & 5 \\
Florida Gulf Coast University & 0 \\
Florida International University & 2 \\
Florida State University & 10 \\
New College of Florida & 6 \\
University of Central Florida & 7 \\
University of Florida & 10 \\
University of North Florida & 1 \\
University of South Florida & 6 \\
University of West Florida & 10 \\
\hline Average score & 5.19 \\
\hline Adapted
\end{tabular}

Adapted from: Performance Based Funding Overview, Florida Board of Governors, 2018

Historically, student retention (i.e. persistence) and academic performance (i.e. achievement) have been the two most frequently assessed outcomes of First-Year Seminars. Second-year retention, in particular, constitutes one of the most common academic progress measures used to evaluate FYS impacts. An abundant body of literature has examined this particular outcome and produced 
compelling evidence on the course potency to improve student academic progress. Overall, positive impacts in this domain constitute a common finding among empirical studies embracing a multitude of research methods (e.g. quantitative, qualitative, mixed, experimental, quasiexperimental) for course participants from all student populations (e.g. at-risk and high-achieving, minority and majority, male and female), and among institutions of all types, control, and sizes (2year and 4-year, public and private, small, mid-sized, and large).

Nationally, FYS courses have been shown as a highly effective intervention in supporting students to progress to the sophomore year of undergraduate education in public 4-year institutions (Burgette \& Magun-Jackson 2009; Clark \& Cundiff, 2011; Cox, Schmitt, Bobrowski, \& Graham, 2005; Miller, Janz \& Chen, 2007; Sidle \& McReynolds, 2009; Tuckman \& Kennedy, 2011). Commensurate effects were noted for FYS participants in community college settings (Cho \& Karp, 2013; Garza \& Bowden, 2014).

The effectiveness of FYS courses in the State of Florida is comparable to national trends. Examining the impacts of the seminars across the state, the Division of Community Colleges within the Florida Department of Education documented that course participants, compared to non-participants, recorded significantly higher rates of continuous college enrollment. Additionally, these positive impacts were not restricted to at-risk students, but were recorded among academically prepared students as well (Florida Department of Education, 2006).

Given that the retention measure for this PF metric is determined by a GPA of 2.0 or above, it is important to include the evidence on the potential of FYS to not only facilitate continuous enrollment, but to support the fulfillment of the required academic threshold. In this regard, empirical findings demonstrates the potency of the seminar to improve not only academic progress, but also students' first-semester and first-year GPA.

National evidence illustrates a positive relationship between FYS participation and increased firstsemester semester GPA across HEIs of all types and sizes. Even though the majority of the findings have been recorded for 4-year public universities (Lang, 2007; Swanson, Vaughan \& Wilkinson, 2017; Tuckman \& Kennedy, 2011; Vaughan, Parra \& Lalonde, 2014), other institutional types seem to benefit in this domain as well. For example, first-semester GPA was found to be higher among seminar participants, compared to non-participants, in 4-year private institutions (Connolly, Flynn, Jemmott, \& Oestreicher, 2017) and community colleges (Ellis \& O-Quinn, 2012; Fowler \& Boylan, 2010; Garza \& Bowden, 2014).

Additionally, course effects on student academic achievement were found to extend beyond firstsemester and into the second year. Again, 4-year public universities have produced the most evidence in this regard (Burgette \& Magun-Jackson, 2009; Noble, Flynn, Lee \& Hilton, 2007; Sidle \& McReynolds, 2009, Williford, Chapman, \& Kahrig, 2001). Even though smaller in scope, significant impacts were recorded for other institutional types such as community colleges (Jamelske, 2009) and liberal arts colleges (Barton \& Donahue, 2009; Starke, Harth, \& Sirianni, 2001).

Lastly, abundant findings have confirmed the seminar efficacy in improving the standing of students who struggled academically, increasing the number of students in good academic 
standing, and decreasing the number of students on academic probation (Fowler \& Boylan, 2010; Mellor, Brooks, Gray, \& Jordan, 2015; Tampke \& Durodoye, 2013; Weiss, Brock, Sommo, Rudd \& Turner, 2011). Of particular interest is the finding that persistence to second-year for high-risk students showed double the improvement of that of low-risk students (Pittendrigh, Borkowski, Swinford \& Plumb, 2016). Lastly, the findings from the state level showed that developmental students in a college in Florida who participated in a FYS course had significantly higher pass rates in their remedial courses than their peers who did not enroll in the course (Griffin \& Romm, 2008).

\section{Metric 2: Four Year FTIC Graduation Rate}

This measure includes the percentage of FTIC students enrolled in Fall (or Summer continuing to Fall) who obtained their bachelor's degree within four years. It is important to note that this particular metric was introduced in March 2018 to replace the previously used, six-year graduation measure (Florida Board of Governors, 2018). This stringent amendment placed additional emphasis on FTIC students' graduation rates, a measure that many institutions still struggle with. Table 5 illustrates 2017-2018 institutional scores for this metric for the State of Florida, when this measure still included six- instead of four-year graduation rates. As it can be seen, the overall score for the members of the State University System of Florida was 4.64, indicating the need for improvement in this area even before the implementation of the new and more rigorous evaluation measure.

Table 5: Institutional Scores for Six-year Graduation Rates in 2017-2018

\begin{tabular}{lc}
\hline \multicolumn{1}{c}{ Institution } & Score \\
\hline Florida Agricultural and Mechanical University & 4 \\
Florida Atlantic University & 0 \\
Florida Gulf Coast University & 5 \\
Florida International University & 0 \\
Florida State University & 10 \\
New College of Florida & 4 \\
University of Central Florida & 8 \\
University of Florida & 10 \\
University of North Florida & 0 \\
University of South Florida & 7 \\
University of West Florida & 3 \\
\hline Average score & 4.64 \\
\hline Adapted fiom: Performance Based Funding Overview, Flor
\end{tabular}

Adapted from: Performance Based Funding Overview, Florida Board of Governors, 2018

In addition to academic progress, graduation rates represent the second most common positive effect of FYS courses. Similar to the first outcome, the positive impacts on the seminar to time to 
degree, persistence to degree, and program completion were not found to be moderated by institutional type and size, seminar type, or student population.

For some universities, FYS courses were most effective in either improving 4-year graduation rates (McGrath \& Burd, 2012; Miller \& Lesik, 2014; Schnell, Louis \& Doetkott, 2003) or enhancing degree attainment within 5-years (Cambridge-Williams, Winsler, Kitsantas \& Bernard, 2013; McGrath \& Burd, 2012; Noble, Flynn, Lee \& Hilton, 2007, Schnell, Louis \& Doetkott, 2003). For other institutions, however, positive course effects were recorded for 4, 5, and 6-year graduation rates simultaneously (Lang, 2007; Starke, Harth, \& Sirianni, 2001; Tuckman \& Kennedy, 2011; Williford, Chapman, \& Kahrig, 2001).

\section{Metric 3: Average Cost to the Student}

This measure refers to net college tuition and fees per 120 credit hours. In the State of Florida, the cost of higher education is calculated based on resident undergraduate tuition and fees, books and supplies, the average number of credit hours attempted by students who were admitted as FTIC students and obtained a bachelor's degree, and financial aid (Florida Board of Governors, 2018).

Even though the research in this domain is not as extensive as the scholarship on FYS impacts on persistence and academic achievement, the existing findings in this area are overwhelmingly positive. For instance, students who participated in the FYS course in a community college setting were found to have earned more college credits within the first year than non-participants (Cho \& Karp, 2013; Karp, Raufman, Efthimou \& Ritze, 2017). Moreover, course participants in one midwestern community college earned imposing 50\% more academic units than their peers who did not take the seminar (Deutch, 1998). The research conducted in 4-year universities further confirmed the course effectiveness on increasing the ratio of attempted and completed credit hours (Sidle \& McReynolds, 2009).

\section{Metric 4: Percent of Bachelor's Graduates Enrolled or Employed}

This PF measure includes all bachelor's degree recipients who are either enrolled or employed in the United States one year after graduation (if employed, minimum annual earnings must be $\$ 25,000)$. This data is inclusive of non-Florida states and districts, as well as the District of Columbia and Puerto Rico (Florida Board of Governors, 2018).

Career exploration and vocational planning constitute common and important topics among modern FYS courses. As mentioned, Barefoot and Fidler's (1992) perennial classification of FYS courses distinguished pre-professional or discipline-based seminars as one of the five traditional categories of FYS courses. Discipline-based FYS are usually embedded in the FYS curricula as a tool for introducing first-year students to a particular major, academic department, or profession. In most cases, they are housed in individual academic departments, but can be also be integrated into institutional First-Year Experience (FYE) programs.

The scholarship on the effectiveness of FYS programs on student career outcomes is consistent in the finding that these courses can be effectively used to promote student career exploration, 
navigation, and readiness. For example, National Survey of Student Engagement (2005), which included students' survey responses from more than 80,000 first-year students, reported the course participants' greater engagement, satisfaction, and development in the area of career advising and planning. Mills (2010) confirmed this finding documenting the course participants more frequent use of career services and increased willingness to seek advice about career plans from seminar instructors or career advisors.

In addition to directly contributing to students' career exploration and planning processes, FYS were found to have a positive impact on participants' long-term goal setting, goal monitoring, and understanding the interrelationship between goals, motivation, and self-regulated learning, all of which constitute important factors of career readiness (Hoops \& Atrip, 2016). This finding was further elaborated by the evidence that FYS can also positively affect student's life-long learning orientations (Padgett, Keup \& Pascarella 2013).

Additionally, the course effectiveness on participants' career readiness can differ among special student populations. For example, international students in a public 4-year institution rated their FYS course as the most effective in preparing them to learn more about career interests. At the same time, however, career exploration was the only learning outcome that these international students rated higher than their domestic peers (Krsmanovic \& Johnson, 2019).

Lastly, the empirical findings in this domain show that FYS courses can be equally beneficial for students who do not have a clearly identified career path. In that regard, evidence exists to support the claim that seminars can be of particular advantage for undecided students. For example, Tampke and Durodoye (2013) supported this premise by recording a strong impact of the seminar on academic performance on undecided students, as indicated by their increased GPA, the percentage of students in good academic standing, and second-semester retention.

Regardless of the approach that FYS programs take to incorporate career readiness in their course curricula, scholarly evidence demonstrates that the benefits of such practice are unequivocally positive. Moreover, these positive impacts seem to only be moderated by the student population, while remaining unaffected by seminar type or students' commitment to a particular major.

\section{Metric 5: Board of Trustees Choice}

Bachelor's degrees awarded to minorities (Metric 10 for Florida Atlantic University, Florida Gulf Coast University, and Florida International University)

This measure includes the total number or percentage of Bachelor's Degrees Awarded to minorities (i.e. non-Hispanic Black and Hispanic students) over one academic year. This measure is not inclusive of non-resident aliens (i.e. international students) and the students with missing race data (Florida Board of Governors, 2018).

The impacts of FYS courses on historically under-represented and other diverse student populations represent the future direction of research on this high-impact practice. At the same time, however, this particular focus represents the major limitation of FYS scholarship and the research area that needs to be supported with a more recent evidence. Thus far, the course effectiveness has been documented for a limited number of diverse student groups, mainly 
international, non-traditional, and first-generation students. Of particular importance for this study are the two minority student groups whose college outcomes determine the funding for several HEIs in the State of Florida: non-Hispanic Black and Hispanic students.

The research on FYS impacts on African-American participants can be traced back to mid-1990s illustrating the positive effects on their second-semester retention and academic performance (Grunder, \& Hellmich, 1996), as well as their second-year persistence (Fidler \& Godwin, 1994). Contemporary findings remain consistent with this early evidence documenting that, even though the majority of course participants benefit from taking the seminar through increased first-semester GPA and first-year persistence, these effects can be even more pronounced for minority students (Swanson, Vaughan \& Wilkinson, 2017). Moreover, the positive course effects on secondsemester persistence were also recorded among Hispanic students, the student population whose academic success, along with African-Americans, determines the state fudging for several institutions in Florida.

While the majority of research in this area examined the seminar benefits for one specific student population, some studies corroborated the claim that FYS can be used to support college success and first-semester performance of both African-American and Hispanic students simultaneously (Connolly, Flynn, Jemmott, \& Oestreicher, 2017). Moreover, these effects were found to extend into the second year, as indicated by the improved second-year GPA and second-year retention for both student groups (Azizova, Clark, Krsmanovic, Johnson, \& Mendez, 2018).

\section{Bachelor Degrees Awarded Annually (Metric 10 for the University of Central Florida)}

This measure refers to the total number of bachelor's degrees awarded in one academic year. The students who earned two distinct bachelor's degrees in one academic year are counted twice, while double majors are counted only once (Florida Board of Governors, 2018).

The effectiveness of FYS courses on this particular performance measure was analyzed and discussed within the following above-investigated metrics: Academic Progress Rate, Four-Year FTIC Graduation Rate, and Average Cost to the student. As illustrated, the findings in this area emerged as overwhelmingly positive regardless of the variable used to measure the course impacts on the number of percent of bachelor's degrees awarded annually (e.g. continuous enrollment, persistence to degree, program completion, number of earned college credits, or the ratio of attempted and completed credits). Moreover, the presented analysis of the interrelationship between FYS outcomes and PF measures revealed that these positive effects remained highly consistent among different institutional types (e.g. public and private, 2 and 4-year, large and midsized) and among diverse student populations.

\section{Discussion}

\section{Significance and Contribution}

This study contributes to addressing one important limitation of the research on First-Year Seminars - the connection of these courses with PF outcomes. Additionally, this study offers an alternative way for examining state and institutional capacities to address their PF outcomes by reforming academic practices and programs. Overall, this research provides several innovative 
insights to understanding how First-Year Seminars relate to PF outcomes and what their potential role is across institutions subject to PF appropriations.

Many policymakers, scholars, and practitioners have emphasized the unintended impacts (i.e. drawbacks) of Performance Funding. The most commonly cited ones include narrowing institutional missions only to the areas defined by PF metrics, neglecting the outcomes not directly related to PF, limiting admission of academically underprepared applicants, and lowering academic standards for admitted students (Dougherty et al., 2016). Among these practices, many institutions admitted weakening their academic standards in order to meet PF metrics, mainly by means of grade inflation or removal of certain academic requirements (Dougherty \& Reddy, 2013). The evidence presented in this paper suggests an educational reform that could maintain the focus on PF outcomes while protecting the academic standards. As supported by the evidence on FYS impacts on student academic progress, GPA, and time to degree, there are several tangible ways in which these courses can potentially assist institutions in meeting their PF outcomes while preserving high academic standards.

Similarly, many institutions operating under PF models reported resorting to the practice of restricting the admission of academically underprepared students which, in many cases, consist of either underrepresented or socioeconomically disadvantaged student groups. In this regard, in particular, the historical overview of findings in this domain suggests that some of the PF challenges can perhaps be alleviated by improving institutional capacity to support these special populations through the implementation of FYS courses. However, a more recent empirical evidence is needed to evaluate if these historical trends can still serve as a rationale for the inclusion of such practices in the PF era. If this proves to be the case, the FYS courses designed to promote college success of special student populations could potentially aid the institutions subject to PF could in reducing their inclination to restrict the admission of these student groups in the fear of their unsatisfactory performance.

Lastly, the scholarship and practice in the domain of Performance Funding have already been characterized by insufficient institutional understanding of PF models as well as poor institutional responses to their PF metrics (Dougherty \& Reddy, 2013). It is also interesting to note that, even though college leaders are largely aware of their PF goals, the levels of such awareness are not comparable among all institutional systems. In fact, the knowledge of PF models within an institution significantly decreases as one moves down the organizational and leadership hierarchy (Dougherty et al., 2016).

In this regard, the intentional alignment of institutional PF measures with FYS outcomes could be introduced as a tool to assist both students, faculty, staff, and stakeholders to become more familiar with the common PF goals. In turn, such increased awareness could help higher education leadership and other catalysts of change more purposefully focus on the improvement in the targeted areas. The ultimate goal of such a practice would be setting HEIs apart from other competing state institutions and increasing their funding opportunities.

\section{Limitations and Future Research}


As discussed in the opening section of this paper, Performance Funding models differ greatly across states. Consequently, the variances among PF types pose different challenges for HIEs subject to these models and offer them different ways in which they can respond to the established metrics. This study, on the other hand, was limited to the case of only one state. The extent to which FYS courses can be utilized to increase the PF outcomes in the remaining 32 states requires a separate empirical investigation.

Next, the overwhelming majority of the studies synthesized in this research assessed the course impacts within only one institution, in relation to only one seminar type, and at only one point in time. Even though limited in scope, evidence exists that not all FYS courses are equally effective in improving student outcomes. Several published studies recorded the lack of course effectiveness in following areas examined in this study: second-semester retention (Barton \& Donahue, 2009; Ellis \& O-Quinn, 2012), second-year retention (Jamelske, 2009; Miller, Janz \& Chen, 2007), second-year GPA (Clark \& Cundiff, 2011; Keup, 2005), and graduation rates (Miller \& Lesik, 2014). In fact, after examining 682 published resources in the area of First-Year Seminars, Permzadian and Crede (2016) found that the effectiveness of these courses can be substantially moderated by seminar characteristics (i.e. seminar type), institutional characteristics (i.e. 2-year or 4-year institutions), and study characteristics (i.e. study design). Moreover, the same findings identified the literature on FYS courses to be characterized by a high" file-drawer effect" or the practice of not publishing non-significant empirical findings. Consequently, it could be argued that the predominantly positive evidence included in this research study might have been the outcome of this effect.

Third, even though the findings of this study implied the connection between the historical evidence on FYS outcomes and current PF measures, this connection must be used with caution and can, by no means, serve as a compelling evidence of FYS courses effectiveness in this domain. Before any such assertions is attempted, the evidence on FYS impacts needs to be examined in a more recent setting and in a direct connection with institutional PF measures.

Therefore, the recommendations provided in this study should be used with caution. Even if PF outcomes improve after introducing or redesigning a particular FYS course, such a change may be caused by many other factors and not necessarily the intervention itself. Hence, it is critical that every institutional change of this type is followed by the empirical assessment that would control for other variables, apart from the FYS course, that might improve PF outcomes. After all, Barefoot and Gardner's (1993) historical but enduring recommendation for implementing an effective FYS courses stated:

Whatever outcomes are intended as a result of the freshman orientation seminar, these outcomes should be evaluated and reported. Freshman seminars share with all non-traditional courses a somewhat tenuous position within the curriculum, and thus they repeatedly must prove themselves effective in order to survive. (Barefoot \& Gardner, 1993, p. 157). 


\section{Implications for Higher Education Institutions}

There are several ways in which the presented findings can be used by HEIs, both in the State of Florida and nationally, to increase institutional awareness of their Performance Funding outcomes. For the State of Florida, the next steps could be directed toward either: (a) introducing FYS courses in the institutions that do not yet offer the courses of this kind or (b) redesigning their existing FYS by more closely aligning the course outcomes with their PF measures. Comparably, the other states subject to performance funding can follow the same binary approach.

For instance, the review of institutional websites for the 10 colleges and universities in the State of Florida listed in Table 4 reveals that, at the time of this study, all HEIs except one offered a FYS course. For these nine institutions, the findings of this research could be used to enhance their freshman seminars by more intentionally focusing on the learning outcomes that are comparable to their PF metrics and that have been identified as related to these metrics. For the institution that has not yet introduced a FYS course, the first step should be utilizing these empirical findings as a tool for identifying the areas of greatest learning gains for course participants and then formulating the course objectives accordingly.

These same implications should be extended to the national level with the addition of one extra step. The HEIs in the states that are subject to PF first need to clearly communicate their performance measures to all institutional entities, especially those that can affect student success and, thus, PF outcomes (i.e. academic programs and services). Next, the institutions with seminar courses could focus on the historical evidence from FYS research related to their PF measures and use this evidence to align their course objectives accordingly. Additional empirical evidence may be needed for other PF measures not examined in this study.

The overarching recommendation and call for action stemming from this study is essentially the one introduced by the creators of FYS courses, Barefoot and Gardner, back in 1993: "All colleges and universities should offer some type of a freshman orientation seminar" (p. 155). The unique recommendation of this study, however, is that for the most effective utilization of FYS for accomplishing specific institutional goals, in this case, the PF measures, a close collaboration of all campus entities needs to be established. In particular, campus academic programs need to have clear lines of communication with high-stake entities, decision-makers, and educational leadership responsible for developing institutional effectiveness plans and influencing funding opportunities. Only by ensuring that the knowledge of PF models within an institution is disseminated to the lowest levels of the organizational hierarchy, can colleges and universities ensure that the effectiveness of their academic programs, in this case, FYS courses, is truly maximized.

\section{References}

Azizova, Z., Clark, M. H., Krsmanovic, M., Johnson, J., \& Mendez, J. P. (2018). Impact of a first-year seminar on retention and academic achievement of students of color in a large urban Hispanic-serving institution. Paper presented at the meeting of the Association for the Study of Higher Education. Orlando, FL.

Barefoot, B. O., \& Fidler, P. P. (1992). National survey of freshman seminar programing: Helping first-year students climb the academic ladder (Monograph No. 10). Columbia, SC: University of South Carolina, Center for the Study of the First Year Experience. Retrieved

fromhttps://files.eric.ed.gov/fulltext/ED354842.pdf 
Barefoot, B. O., \& Gardner, J. N. (1993). The freshman orientation seminar: Extending the benefits of traditional orientation. In M. L. Upcraft, R. H. Mullendore, B. O. Barefoot, \& D. S. Fidler, (Eds.), Designing successful transitions: A guide to orienting students to college (pp. 141-154). Columbia, SC: University of South Carolina.

Barton, A., \& Donahue, C. (2009). Multiple assessment of a first-year seminar pilot. The Journal of General Education, 58(4), 259-278. doi: 10.1353/jge.0.0051

Burgette, J. E., \& Magun-Jackson, S. (2009). Freshman orientation, persistence, and achievement: A longitudinal analysis. Journal of College Student Retention, 10(3), 235-263. doi: 10.2190/CS.10.3.a

Burke, J. C. (2002). Funding public colleges and universities for performance. Albany, NY: Rockefeller Institute Press.

Cambridge-Williams, T., Winsler, A., Kitsantas, A., \& Bernard, E. (2013). University 100 orientation courses and living-learning communities boost academic retention and graduation via enhanced self-efficacy and selfregulated learning. Journal of College Student Retention, 15(2), 243-268. doi: 10.2190/CS.15.2.f

Cho, S. W., \& Karp, M. M. (2013). Student success courses in the community college: Early enrollment and educational outcomes. Community College Review, 41(1), 86-103. doi: 10.1177/0091552112472227

Clark, M. H., \& Cundiff, N. L. (2011). Assessing the effectiveness of a college freshman seminar using propensity score adjustments. Research in Higher Education, 52, 616-639. doi: 10.1007/s11162-010-9208-X

Connolly, S., Flynn, E. E., Jemmott, J., \& Oestreicher, E. (2017). First year experience for at-risk college students. College Student Journal, 51(1), 1-6. Retrieved from https://eric.ed.gov/?id=EJ1132169

Cox, P. L., Schmitt, E. D., Bobrowski, P. E., \& Graham, G. (2005). Enhancing the first-year experience for business students: Student retention and academic success. Journal of Behavioral and Applied Management, 7(1), 40-68. Retrieved from http://connection.ebscohost.com/c/articles/19164168/enhancing-first-yearexperience-business-students-student-retention-academic-success

Deutch (1998). Oakton Community College. In B. O. Barefoot, C. L. Warnock, M. P. Dickinson, S. E. Richardson, \& M. R. Roberts (Eds.), Exploring the evidence, Volume II: Reporting outcomes of first-year seminars (Monograph No. 29) (pp. 11-12). Columbia, SC: University of South Carolina, National Resource Center for The First-Year Experience and Students in Transition.

Dougherty, K. J., \& Natow, R. S. (2015). The politics of performance funding for higher education: Origins, discontinuations, and transformations. Baltimore, MD: John Hopkins University Press.

Dougherty, K. J., \& Reddy, V. (2013). Performance funding for higher education: What are the mechanisms? What are the impacts? (ASHE Higher Education Report). San Francisco, CA: Jossey-Bass.

Dougherty, K. J., Jones, S. M., Lahr, H., Natow, R. S., Pheatt, L. \& Reddy, V. (2016). Performance funding for higher education. Baltimore, MD: John Hopkins University Press

Ellis-O'Quinn, A. (2012). An ex post facto study of first-year student orientation as an indicator of student success at a community college. Inquiry, 17(1), 51-57. Retrieved from https://eric.ed.gov/?id=EJ974774

Fidler, P. P., \& Godwin, M. A. (1994). Retaining African-American students through the freshman seminar. Journal of Developmental Education, 17(3), 34-40. Retrieved from https://eric.ed.gov/?id=EJ479880

Florida Board of Governors (2018). Performance based funding model. Retrieved from: https://www.flbog.edu/board/office/budget/performance_funding.php

Florida Department of Education (2006). Data trends \#31: Taking student life skills course increases academic success. Tallahassee, FL: Florida Department of Education.

Fowler, P. R., \& Boylan, H. R. (2010). Increasing student success and retention: A multidimensional approach. Journal of Developmental Education, 34(2), 2-10. Retrieved from https://eric.ed.gov/?id=EJ986268

Gall, M. D., Gall, J. P., \& Borg, W. R. (2006). Educational research: An introduction (8 ${ }^{\text {th }}$ ed). Boston, MA: Allyn \& Bacon.

Garza, E., \& Bowden, R. (2014). The impact of a first year development course on student success in a community college: An empirical investigation. American Journal of Educational Research. 2(6): 402-419. doi: 10.12691/education-2-6-13.

Gordon, V. N. (1991). The evolution of a freshman seminar course: A case study. Journal of the Freshman Year Experience, 3(2), 107-116. Retrieved from www.ingentaconnect.com/content/fyesit/fyesit/1991/00000003/00000002/art00007

Griffin, A. M., \& Romm, J. (Eds.). (2008). Exploring the evidence: Reporting research on first-year seminars (Vol. $I V)$. Columbia, SC: National Resource Center for the First-Year Experience and Students in Transition. Retrieved from http://www.sc.edu/fye/resources/fyr/index.html 
Grunder, P. G., \& Hellmich, D. M. (1996). Academic persistence and achievement of remedial students in a community college's College Success Program. Community College Review, 24(2), 21-33. Retrieved from https://archive.org/details/academicpersiste00grun

Hunter, M. A., \& Linder, C. W. (2005). First-year seminars. In M. L. Upcraft, J. N. Gardner, B. O. Barefoot, \& Associates (Eds.), Challenging and supporting the first-year student: A handbook for improving the first year of college (pp. 275-291). San Francisco, CA: Jossey-Bass.

Institute of Education Sciences. (2016). WWC intervention report. First year experience courses. Retrieved from https://ies.ed.gov/ncee/wwc/Docs/InterventionReports/wwc_firstyear_102116.pdf

Hoops, L. D., \& Artrip, A. (2016). College student success course takers' perceptions of college student effectiveness. Learning Assistance Review, 21(2), 55-67. Retrieved from https://eric.ed.gov/?id=EJ1114471

Jamelske, E. (2009). Measuring the impact of a university first-year experience program on student GPA and retention. Higher Education, 57(3), 373-391. Retrieved from https://eric.ed.gov/?id=EJ825726

Karp, M. M., Raufman, J., Efthimiou, C., \& Ritze, N. (2017). Revising a college 101 course for sustained impact: Early outcomes. Community College Journal of Research and Practice, 41(1), 42-55, doi: $10.1080 / 10668926.2016 .1152929$

Keup, J. R. (2005). The impact of curricular interventions on intended second-year re-enrollment. Journal of College Student Retention, 7(1-2), 61-89. doi: 10.2190/2DCU-KABY-WVQH-2F8J

Krsmanovic, M., \& Johnson, J. D. (2019). International students' academic and sociocultural adjustment to college: A mixed-method exploration of current perceptions and future possibilities. Paper presented at the meeting of American Educational Research Association. Toronto, Canada.

Lang, D. J. (2007). The impact of first-year experience course on the academic performance, persistence, and graduation rates of first-semester college students at a public research university. Journal of the First-Year Experience \& Students in Transition, 19(7), 9-25. Retrieved from http://eric.ed.gov/?id=EJ798191

McGrath, S. M., \& Burd, G. D. (2012). A success course for freshmen on academic probation: Persistence and graduation outcomes. NACADA Journal, 32(1), 43-52. Retrieved from https://eric.ed.gov/?id=EJ973057

Mellor, D. T., Brooks, W. R., Gray, S. A., \& Jordan, R. C. (2015). Troubled transitions into college and the effects of a small intervention course. Journal of College Student Retention: Research, Theory \& Practice, 17(1) 44-63. doi: 10.1177/1521025115571102

Miller, J. W., \& Lesik, S. S. (2014). College persistence over time and participation in a first-year seminar. Journal of College Student Retention, 16(3), 373-390. doi: 10.2190/CS.16.3.d

Miller, J. W., Janz, J. C., \& Chen, C. (2007). The retention impact of a first-year seminar on students with varying pre-college academic performance. Journal of the First-Year Experience and Students in Transition, 19(1), 47-62. Retrieved from https://eric.ed.gov/?id=EJ798193

Mills, M. T. (2010). Tools of engagement: Success course influence on student engagement. Journal of the FirstYear Experience \& Students in Transition, 22(2), 9-32. Retrieved from https://eric.ed.gov/?id=EJ906628

National Resource Center for The First-Year Experience and Students in Transition. (2013). 2012-2013 National survey of first-year seminars. The University of South Carolina. Retrieved from http://sc.edu/fye/research/surveys/survey_instruments/pdf/Executive_Summaries_2013_National_Survey_ FirstYearSeminars.pdf

National Survey of Student Engagement. (2005). Exploring different dimensions of student engagement:2005 annual results. Retrieved from http://nsse.iub.edu/pdf/NSSE2005_annual_report.pdf

Noble, K., Flynn, N. T., Lee, J. D., \& Hilton, D. (2007). Predicting successful college experiences: Evidence from a first year retention program. Journal of College Student Retention: Research, Theory \& Practice, 9(1), 3960. Retrieved from https://eric.ed.gov/?id=EJ762087

Padgett, R. D., Keup, J. R., \& Pascarella, E. T. (2013). The impact of first-year seminars on college students' lifelong learning orientations. Journal of Student Affairs Research and Practice, 50(2), 133-151. doi: 10.1515/jsarp-2013-0011

Pittendrigh, A., Borkowski, J., Swinford, S., \& Plumb, C. (2016). Knowledge and community: The effect of a firstyear seminar on student persistence. The Journal of General Education, 65(1), 48-65. Retrieved from https://muse.jhu.edu/article/626139

Schnell, C. A., Louis, K. S., \& Doetkott, C. (2003). The first-year seminar as a means of improving college graduation rates. Journal of The First-Year Experience, 15(1), 53-76. doi: 10.3102/0034654315584955

Sidle, M. W., \& McReynolds, J. (2009). The freshman year experience: Student retention and student success. NASPA Journal, 46(3), 434-446. Retrieved from https://eric.ed.gov/?id=EJ609372 
Starke, M. C., Harth, M., \& Sirianni, F. (2001). Retention, bonding, and academic achievement: Success of a firstyear seminar. Journal of the First Year Experience, 13(2), 7-35. Retrieved from http://eric.ed.gov/?id=EJ643340

Swanson, N. M., Vaughan, A. L., \& Wilkinson, B. D. (2017). First-year seminars: Supporting male college students' long-term academic success. Journal of College Student Retention: Research, Theory \& Practice, 18(4), 386-400. doi: 10.1177/1521025115604811

Tampke, D. R., \& Durodoye, R. (2013). Improving academic success for undecided students: A first-year seminar/learning community approach. Learning Communities Research and Practice, 1(2). Retrieved from https://eric.ed.gov/?id=EJ1112851

Tuckman, B. W., \& Kennedy, G. J. (2011). Teaching learning strategies to increase success of first-term college students. The Journal of Experimental Education, 79, 478-504. doi: 10.1080/00220973.2010.512318

Vaughan, A., Parra, J., \& Lalonde, T. (2014). First-generation college student achievement in the first-year seminar: A quasi-experimental design. Journal of the First-Year Experience \& Students in Transition, 26(2), 51-67. Retrieved from https://eric.ed.gov/?id=EJ1047352

Weiss, M., Brock, T., Sommo, C., Rudd, T., \& Turner, M. C. (2011). Serving community college students on probation: Four-year findings from Chaffey College's Opening Doors. Report. New York: MDRC. Retrieved from https://eric.ed.gov/?id=ED526395

Williford, A. M., Chapman, L. C., \& Kahrig, T. (2001). The university experience course: A longitudinal study of student performance, retention, and graduation. Journal of College Student Retention: Research, Theory \& Practice, 2(4), 327-340. Retrieved from https://eric.ed.gov/?id=EJ625068

Yin, R. K. (2009). Case study research: Design and method ( ${ }^{\text {th }}$ ed.). Thousand Oaks, CA: Sage. 